\title{
Occurrence of Lepidimoide-like Substance in Growing Plant Tissues and its Physiological Activity in Arabidopsis thaliana*
}

\author{
Hiroshi Nabetani**, Nobuharu Goto**, Kaori Tomita-Yokotani***, Koji Hasegawa*** \\ and Katsutoshi Hirose $e^{* * *}$
}

\begin{abstract}
Lepidimoide, which was first identified as an allelopathic substance, was roughly confirmed to be included in growing tissues (rosette leaves, stems + inflorescences and roots) of Arabidopsis thaliana by means of HPLC analysis. Peaks of retention time in HPLC of the lepidimoide fractions extracted from the above organs completely coincided with that of authentic lepidimoide.

The lepidimoide-like substance, which was contained in the fraction below MW 3000 in the molecular exclusion chromatography, promoted hypocotyl growth and inhibited root growth of cockscomb (Celosia cristata). The substance also promoted the growth of hypocotyls and cotyledon-petioles, increased the area of cotyledons, but inhibited the root growth of $A$. thaliana seedlings. These facts suggest that the lepidimoide-like substance may play some role as an endogenous plant growth regulator in growing plants of $A$.
\end{abstract}

* This work was supported in part by a Grant-inAid from the Ministry of Education, Science, Sports and Culture, Japan (No. 09640761). A part of this paper was reported at The 2000 Annual Meeting of The Japanese Society of Plant Physiologists (Nagoya).

** Department of Biology, Miyagi University of Education, Aramaki, Aoba, Sendai 980-0845, Japan

*** Institute of Applied Biochenistry, University of Tsukuba, Ibaraki 305-8572, Japan

**** Kobe Natural Products \& Chemicals Co., Ltd., Ohkubo-Cho, Akashi 674-0067, Japan

(Received February 16, 2000 : Accepted July 4, 2000) thaliana.

Key words: Arabidopsis thaliana, lepidimoide, plant growth regulator, growth promotion, growth inhibition

\section{Introduction}

Lepidimoide was first identified as an allelopathic substance in germinated cress seeds by the mixed culture test ${ }^{5}$. When cress seeds were placed near cockscomb, tomato or lettuce seeds for germination in a seed bed, the hypocotyl growth in the latter seedlings was promoted, but their root growth was inhibited. In this case the growth of the cress seedlings was not affected by the other plants ${ }^{5,6)}$. Thereafter, germinated seeds of various dicots, sunflowers and buckwheat, in particular ${ }^{8,15)}$, as well as monocots were found to secrete a lepidimoide-like substance. Generally, allelopathic substances have an inhibitory effect on plant growth, for example, 2-cis-dehydromatricaria ester from seeds of Solidago altissima ${ }^{10)}$, and 5-hydroxynaphthoquinone (juglone) from the stone fruits of walnuts ${ }^{1}$. However, lepidimoide is a unique substance in the respect that it promotes the seedling growth of other plants ${ }^{7}$.

Lepidimoide, named after the scientific name of cress, Lepidium sativum L., is a disaccharide composed of glucose and rhamnose (Fig. 1). The chemical structure of the substance has been determined and synthes- 


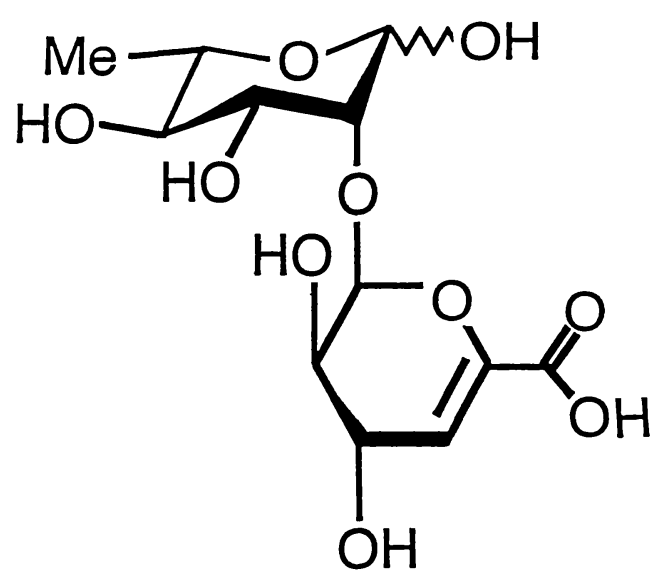

Fig. 1 Chemical structure of lepidimoide.

ized from glucose and rhamnose ${ }^{12)}$. There is a report that ceratin oligosaccharides (raffinose and stachyose) promoted the Arabidopsis growth in leaf number and dry weight ${ }^{9}$. Since lepidimoide belongs to the disaccharide group, there may be a common process of growth promotion functioning similar to the oligosaccharide action.

Lepidimoide promotes hypocotyl growth but inhibits root growth, particularly of plants belonging to Amaranthaceae, such as Celosia cristata and Amaranthus caudatus ${ }^{8}$. Several other physiological effects have been investigated. Promotion of hypocotyl growth, rosette leaf development, plant height, plant mass, and acceleration of flowering in Arabidopsis thaliana ${ }^{4}$; inhibition of senescence in Avena leaf segment ${ }^{13)}$; and inhibition of abscission of bean petiole explants ${ }^{14)}$ have been reported. These studies suggest that lepidimoide is not only an allelopathic substance but also a common plant growth regulating substance. We have found that germinated seeds of $A$. thaliana contain lepidimoide $^{17 \text { ). }}$.

In this article we report the occurrence of a lepidimoide-like substance from various organs of growing plants of $A$. thaliana and also on its physiological activities during seedling growth.

\section{Materials and Methods}

\section{Chemicals}

Authentic lepidimoide (Na 2-O-Lrhamnopyranosyl 4-deoxy- $\alpha$-L-threo-hex-4enopyranosiduronate, Fig. 1) was synthesized from D-glucose and $\alpha$-L-rhamnose as described by Kosemura et al. ${ }^{12}$.

\section{Extraction and isolation of lepidimoide-like substance}

Arabidopsis thaliana L. Heynh. (Shokei line) was cultivated in a field in Sendai, Japan, from October 1997 to April 1998. The plants that were about to flower and those whose flower stalks were $2-10 \mathrm{~cm}$ high with just-opened flowers were collected. The plants were separated into roots, rosette leaves and stems + inflorescences.

Each organ was frozen with liquid nitrogen and ground by mortar and pestle. The frozen powder of the roots (ca. $10 \mathrm{~g}$ in fresh weight), rosette leaves (ca. 130g in fresh weight) and stems + inflorescences (ca. 190g in fresh weight) was extracted in boiling water (11 in roots and 31 in rosette leaves and in stems + inflorescences) for $30 \mathrm{~min}$. The water extract was evaporated in a vacuum at $40^{\circ} \mathrm{C}$ to $200 \mathrm{ml}$, and the concentrate was centrifuged (10000 $\mathrm{rpm}, 15 \mathrm{~min})$. The supernatant was evaporated to dryness in a vacuum at $40^{\circ} \mathrm{C}$. The residue was dissolved in water $(100 \mathrm{ml})$ and fractionated by chloroform 3 times. The water phase was evaporated to dryness in a vacuum at $40^{\circ} \mathrm{C}$. The residue dissolved in water was fractionated successively into four parts (MW above $10^{5}$, from $10^{5}$ to $10^{4}$, from $10^{4}$ to $10^{3}$, and below $10^{3}$ ) by molecular exclusion chromatography (Novacell, Filtron Technology Co., USA).

We used the fraction below MW $10^{3}$, in 
which lepidimoide was included. This fraction, called 'lepidimoide-like substance', was concentrated to dryness in a vacuum at $40^{\circ} \mathrm{C}$, and separated it into 2 parts for HPLC (high performance liquid chromatography) analysis and for bioassay.

\section{HPLC analysis}

The lepidimoide-like substance dissolved in water was applied to three solid-phase extractions with Sep-Pak Plus Cartridges (Waters Co., USA): C18, Accell CM and Accell QMA, in that order. In the first step, the 10-ml sample was applied to a reversephase cartridge column (Sep-Pak Plus, C18) and washed with $5 \mathrm{ml}$ water. The combined sample was appiled to a cation-exchange cartridge column (Sep-Pak Plus, Accell CM). The unadsorbed fraction was applied to an anion-exchange cartridge column (Sep-Pak Plus, Accell QMA), washed with $5 \mathrm{ml}$ each of water and $0.01 \%$ trifluoroacetic acid, and then eluted with $20 \mathrm{ml}$ of $0.1 \%$ trifluoroacetic acid. The effluent was evaporated to dryness in a vacuum at $40^{\circ} \mathrm{C}$. In some cases, to obtain a more purified sample, the residue dissolved in water was fractionated below MW 5000 by molecular exclusion chromatography (Mol Cut, UFP2 LCC24, Nihon Millipore, Ltd. Japan). The sample was freeze-dried and stored at $-26^{\circ} \mathrm{C}$.

The stored sample was dissolved in water and was then purified by HPLC (Tosoh, SCX $(\mathrm{H}+) ; \phi 7.8 \mathrm{~mm} \mathrm{I}$. D. $\times 300 \mathrm{~mm}$; water, flow rate $0.8 \mathrm{ml} / \mathrm{min}, 214 \mathrm{~nm}$ detector). The eluate retained for 5 to $7 \mathrm{~min}$ was collected in which lepidimoide was contained ${ }^{16)}$. For an assay of biological activity, this fraction was collected more than 20 times. The combined effluent was evaporated to dryness in a vacuum at $40^{\circ} \mathrm{C}$. This final sample was applied to the biological assay. After confirmation of the biological activity, the sample was reapplied to HPLC singly and/or mixed with authentic lepidimoide.

\section{Bioassay}

Cockscomb test: Fifteen cockscomb seeds (Celosia cristata L.) were placed on filter paper (Advantec Toyo, No. 101) moistened with $0.5 \mathrm{ml}$ of test solution in a $3-\mathrm{cm}$ petri dish. The petri dishes were kept in darkness at $25^{\circ} \mathrm{C}$ for 4 days. The lengths of the hypocotyls and roots were then measured.

Arabidopsis test: Thirty seeds of Arabidopsis thaliana L. Heynh. (WS and/or Columbia line) were sown on $1 \%$ agar with $3 \mathrm{ml}$ of test solution in a $3-\mathrm{cm}$ petri dish. The petri dishes, placed in a moistened transparent plastic tray, were kept in darkness at $5^{\circ} \mathrm{C}$ for 2 days and then allowed to grow under continuous light (ca. $10 \mathrm{~W} / \mathrm{m}^{2}$ ) at $23^{\circ} \mathrm{C}$ for 7 days. The lengths of the hypocotyls and cotyledonpetioles, and the areas of the cotyledons were mearured with a photographic enlarger with $0.1 \mathrm{~mm}$ accuracy. To measure root length, seeds were sown on a $1 \%$-agar plate with $10 \mathrm{ml}$ of test solution in a square plastic dish $(8 \times 7 \times 2 \mathrm{~cm})$ and kept in darkness at $5^{\circ} \mathrm{C}$ for 2 days. The dish was then placed in a vertical position so as to let the roots grow downward along the agar surface. The root length was measured after incubation under continuous light at $23^{\circ} \mathrm{C}$ for 7 days.

\section{Results}

\section{Biological activity of lepidimoide-like sub- stance on cockscomb seedlings}

The lepidimoide-like substance from roots, rosette leaves and stems + inflorescences were applied to the cockscomb test (Fig. 2). As shown in Fig. 2A, the samples from rosette leaves and those from stems + inflorescences showed marked promotion of the cockscomb hypocotyls, which grew to approximately twice the length of the control 

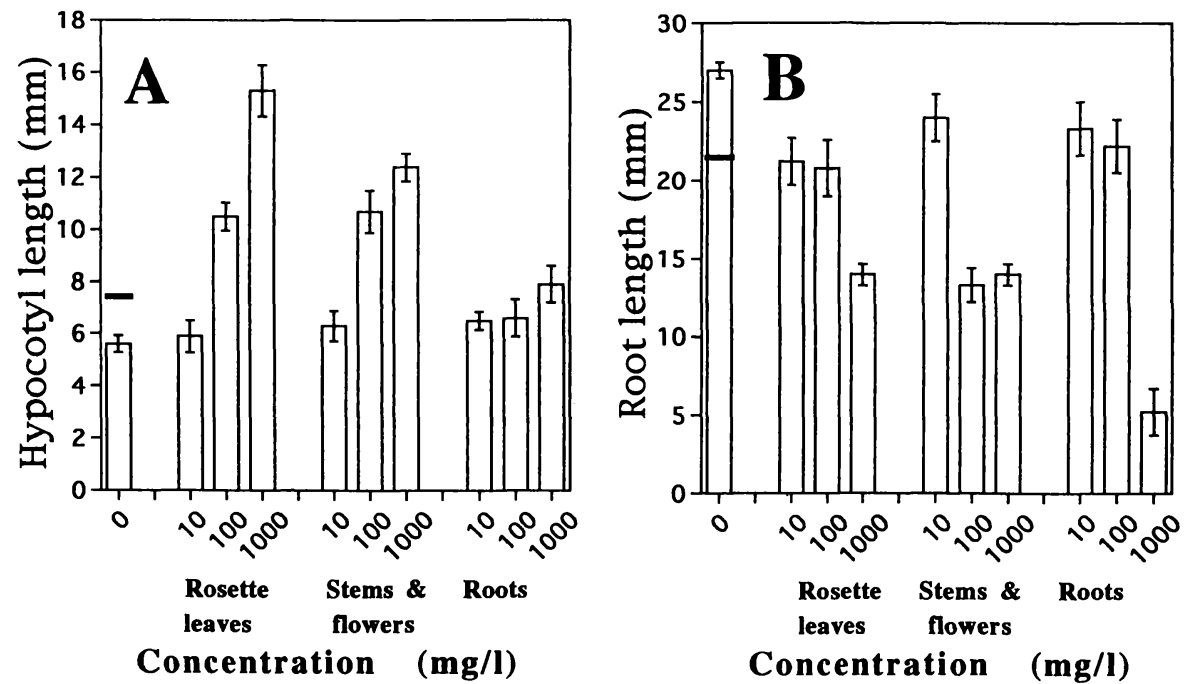

Fig. 2 Effects of lepidimoide-like substance from rosette leaves, stems + inflorescences and roots of $A$ rabidopsis thaliana (Shokei line) on hypocotyl and root growth of cockscomb. A: Hypocotyl length. B: Root length. Bars indicate $\mathrm{SE}$ of the mean $(\mathrm{n}=12)$. Horizontal bars on concentration 0 indicate the effect of authentic lepidimoide $(1000 \mathrm{mg} / \mathrm{l})$.

at $100 \mathrm{mg} / 1$. The fraction of rosette leaves at $1000 \mathrm{mg} / 1$ showed about 3-fold elongation compared with the control. The fraction of roots showed a small promoting effect at $1000 \mathrm{mg} / 1$. Figure $2 B$ shows the effect of the lepidimoide-like substance on the growth of cockscomb roots. All three fractions showed a remarkable inhibitory effect on cockscomb root growth at $1000 \mathrm{mg} / \mathrm{l}$; many short lateral roots occurred instead of elongated main roots. No significant effect was observed in the cockscomb hypocotyl test of gibberellin $\mathrm{A}_{3}\left(\mathrm{GA}_{3}\right)$, indoleacetic acid (IAA) and benzyladenine (BA) at a concentration of $10^{-4} \mathrm{M}$ (data not shown).

\section{Biological activity of lepidimoide-like sub-} stance on $A$. thaliana seedlings

The Arabidopsis test was applied to the lepidimoide-like substance extracted from rosette leaves. Figure 3 shows the effects of the substance on four growth processes of
WS and Columbia lines. The hypocotyl length of the WS line was promoted in proportion to rising concentration between 10 and $10^{3} \mathrm{mg} / 1$, but at $10^{4} \mathrm{mg} / 1$ the seedlings showed no further growth (Fig. 3A). In the Columbia line the hypocotyl growth was enhanced at $10^{3}$ $\mathrm{mg} / \mathrm{l}$, but the degree of growth promotion decreased at $10^{4} \mathrm{mg} / 1$. Root growth in both lines was severely inhibited at concentrations over $10^{2} \mathrm{mg} / 1$ and did not occur at $10^{4} \mathrm{mg} / 1$ (Fig. 3B). Cotyledon area and petiole length increased at a concentration of $10^{3} \mathrm{mg} / 1$ in the WS line (Fig. 3C, 3D and Fig. 4) and of $10^{3}$ and $10^{4} \mathrm{mg} / 1$ in the Columbia line (Fig. $3 \mathrm{C}$ and 3D).

These results indicate that the Columbia line is less sensitive to the growth inhibiting action of a high concentration of the lepidimoide-like substance compared with the WS line. Similar activity was recognized in the substance from stems + inflorescences (date not shown).

Sucrose (1\%) and glucose (1\%) did not 

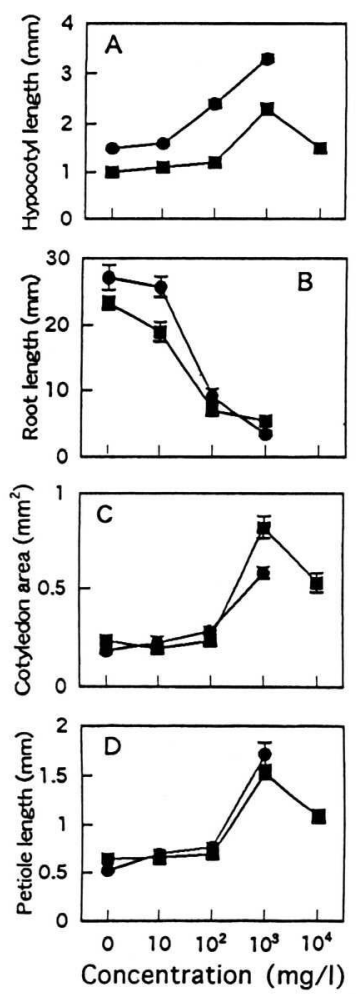

Fig. 3 Effects of lepidimoide-like substance from rosette leaves of $A$. thaliana (Shokei line) on some growth indicators of $A$. thaliana seedlings. A: Hypocotyl length. B: Root length. C: Cotyledon area. D: Petiole length. Circles: WS line. Squares: Columbia line. Bars indicate SE of the mean $(n=25)$. The error bars that are not visible are contained within the symbol.

affect any growth process after 7 days incubation (data not shown). This shows that the lepidimoide-like substance does not act as a nutrient source.

\section{HPLC analysis of lepidimoide-like sub- stance}

The three samples (rosette leaves, stems + inflorescences and roots) dissolved in water were purified by HPLC. Eluate from 5 to 7 min in which lepidimoide was contained and that from 7 to $10 \mathrm{~min}$ were collected. The retention time of authentic lepidimoide was 5 .

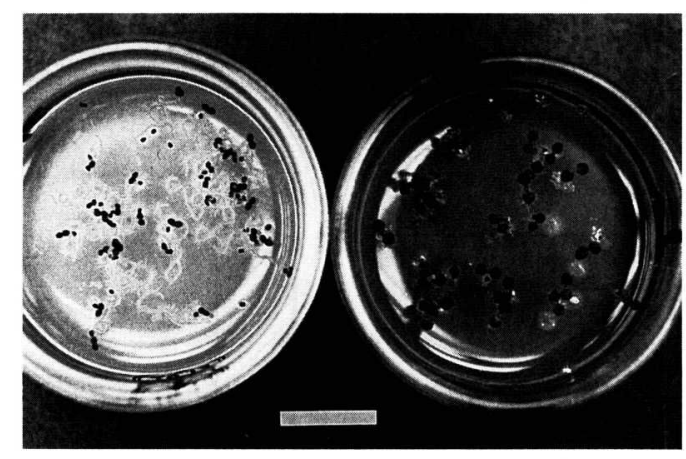

Fig. 4 Effect of lepidimoide-like substance from rosette leaves of $A$. thaliana (Shokei line) on cotyledon area of WS line. Seedlings were incubated on an agar plate in a small petri dish for 7 days under continuous light at $23^{\circ} \mathrm{C}$. Left: Control. Right: lepidimoide-like substance $1000 \mathrm{mg} / 1$. Bar $=10 \mathrm{~mm}$.

$5 \mathrm{~min}$. The biological activity of the eluates was assayed by the cockscomb test. The sample of rosette leaves revealed growth promotion of hypocotyls and growth inhibition of roots in cockscomb seedlings (Fig. 5). Samples from stems + inflorescences and roots showed similar effects to the rosette leaves (data not shown).

The eluate containing the lepidimoide-like substance was evaporated to dryness in a vacuum at $40^{\circ} \mathrm{C}$. The residue dissolved in water was finally applied to HPLC (column and conditions were the same as in Materials and Methods). The retention time of each sample from the 3 organs (leaves, stems + inflorescences and roots) was compared with authentic lepidimoide (Fig. 6). The peaks of the extracted sample completely coincided with that of authentic lepidimoide in all cases of the rosette leaves (Fig. 6, left), stems + inflorescences (Fig. 6, middle) and roots (Fig. 6 , right). The peaks also coincided with those of the chromatograms of authentic lepidimoide (Fig. 6, top row), extracted sample (Fig. 6, middle row), and the mixture of authentic lepidimoide and extracted sample 

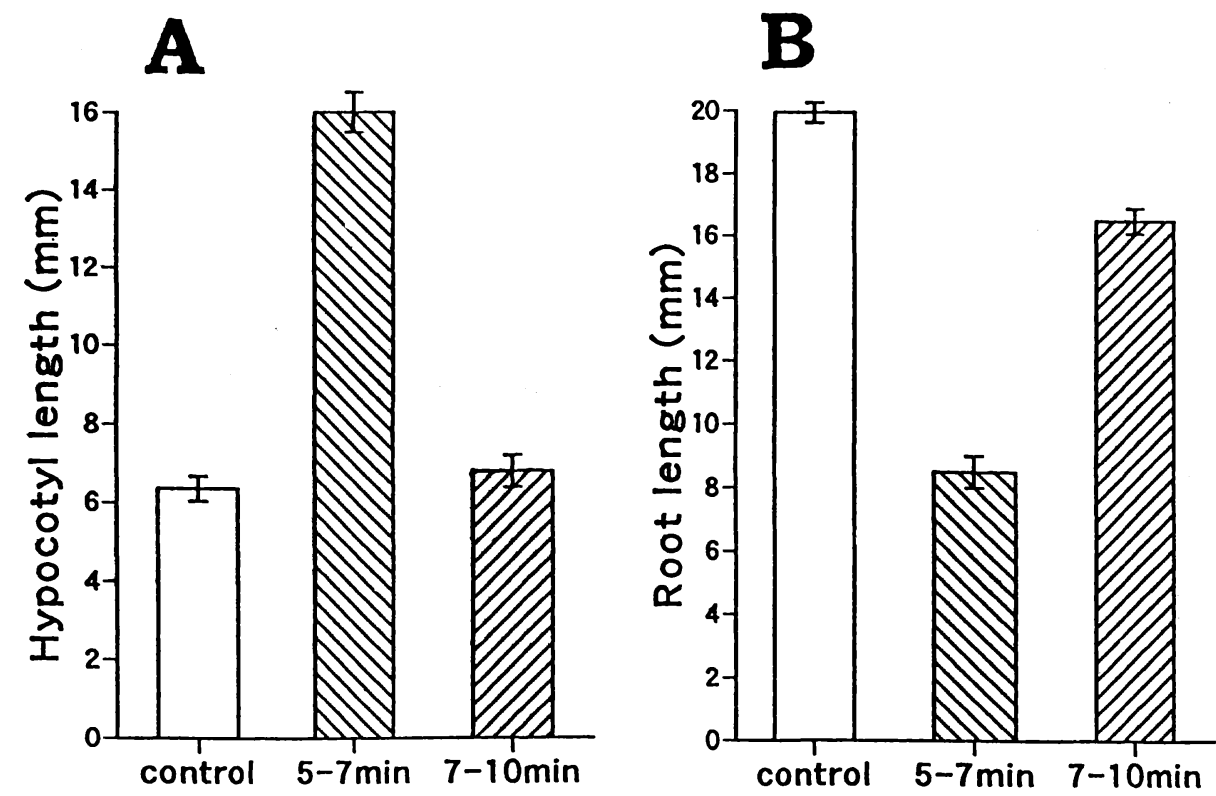

Fig. 5 Effects of HPLC fraction prepared from rosette leaves of $A$. thaliana (Shokei line) on hypocotyl and root growth of cockscomb. Biological actibity was assayed for fractions with retention times of 5-7 and 7-10 min. A: Hypocotyl length. B: Root length. Bars indicate SE of the mean $(n=12)$.

(Fig. 6, bottom row). From this result we concluded that the lepidimoide-like substance in the growing tissues almost certainly coincided with or contained lepidimoide.

\section{Discussion}

Lepidimoide is an allelopathic substance at the germination stage ${ }^{5,6,8)}$. It can also be considered as a growth regulating substance in growing plants ${ }^{4}$. Lepidimoide is a unique allelopathic substance because of having a two-faced effect: a growth promoting and a growth inhibiting effect. Most allelopathic substances have growth-inhibiting effects on plants, but lepidimoide shows growthpromoting effects on hypocotyls ${ }^{7,8)}$ and flower stalks ${ }^{4}$, and growth-inhibiting effects on roots $^{7}$.

We have heretofore believed that lepidimoide was exuded from germinated seeds in cress ${ }^{15)}$. Additionally, in A. thaliana it was produced in the testa and secreted from the 'central elevation' of the testa cells together with mucilage ${ }^{2,3,11)}$. In the present experiment, we found by HPLC analysis that lepidimoide is also included in growing rosette leaves, flower stalks, inflorescences and roots of $A$. thaliana. The amount of lepidimoide-like substance was roughly estimated by the cockscomb hypocotyl test on the basis of the kinetics of authentic lepidimoide: $1.5 \mathrm{mg} / \mathrm{g}$ fresh weight in rosette leaves, $0.3 \mathrm{mg} / \mathrm{g}$ fresh weight in stems + inflorescences, $0.08 \mathrm{mg} / \mathrm{g}$ fresh weight in roots and $0.6 \mathrm{mg} / \mathrm{g}$ weight of fully ripened seeds. The order, in descending quantity, was rosette leaves $>$ stems + inflorescences $>$ roots. This suggests that lepidimoide is mainly synthesized in rosette leaves. However, the amounts of the lepidimoide-like substance were beyond our 


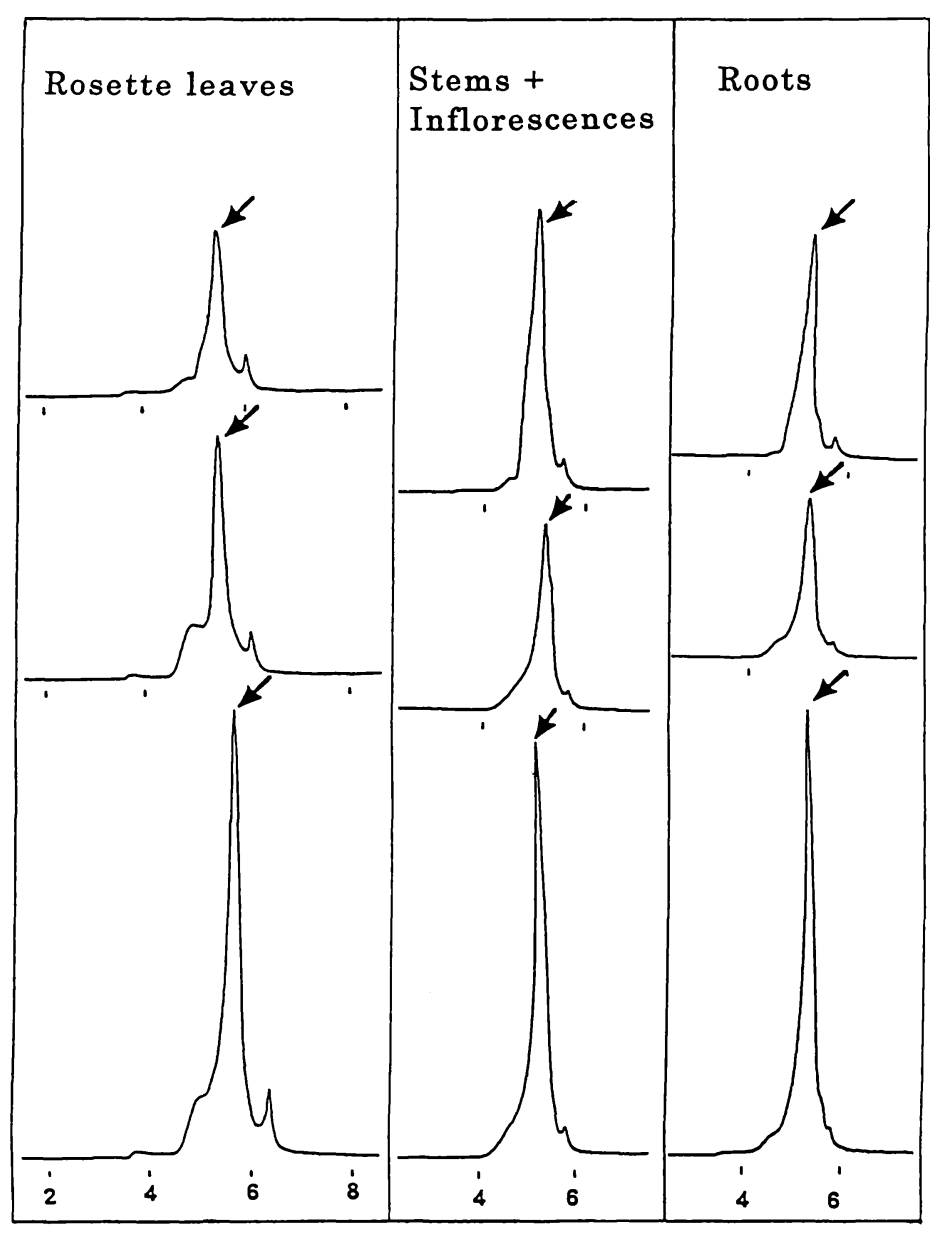

Retention time (min)

Fig. 6 HPLC chromatograms of lepidimoide-like substance in rosette leaves, stems + inflorescences and roots of A. thaliana (Shokei line). Left to right: Rosette leaves, Stems + Inflorescences, Roots, Top row: Chromatogram of authentic lepidimoide, Middle row: Chromatogram of extracted sample, Bottom row: Chromatogram of mixture of authentic lepidimoide and extracted sample. Arrows indicate peaks of lepidimoide.

expectations. This overestimation may have been caused by the relatively low efficacy of authentic lepidimoide (Fig. 2). We are now investigating the reason for this low efficacy.

For an assay of lepidimoide, the cockscomb test using Celosia cristata or Amaranthus caudatus is the best at present. Cockscomb seedlings responded negatively to auxin (IAA) and were little pormoted by $\mathrm{GA}_{3}{ }^{7)}$ or sugars ${ }^{16)}$. We recognized that the lepidimoide- like substance, as well as IAA and BA, was not effective on lettuce hypocotyl growth in the light, although $\mathrm{GA}_{3}$ markedly promoted the elongation of lettuce hypocotyls at even a low dose of $10^{-6} \mathrm{M}$. (data not shown). From these results we believe that the lepidimoidelike substance acts in a different manner than gibberellin action. In $A$. thaliana, this substance promoted hypocotyl elongation at the somewhat high concentration of $1000 \mathrm{mg} / 1$, 
but inhibited root elongation at the lower concentration of $100 \mathrm{mg} / 1$ (Fig. 3). The effective concentrations are much higher than those in other plant hormones or oligosaccharides active in plant growth"), but the effect is not that of sugar nutrients, because both glucose and sucrose scarcely promoted the growth of hypocotyls, cotyledons and petioles (data not shown). There are some differences among wild-type lines in regard to the efficacy, i. e. the WS line showed a greater promotion than Columbia line in hypocotyl growth, but the reverse was true in terms of cotyledon growth (Fig. 3). Generally, the sensitivity to lepidimoide differs greatly among wild-type lines ${ }^{4}$.

We could not identify lepidimoide in the growing plant tissues of $A$. thaliana, although the HPLC peaks of the lepidimoide-like substance completely coincided with those of authentic lepidimoide. Studies to identify this substance are in progress.

Acknowledgement: The authors are grateful to Dr. K. Yamada, Institute of Applied Biochemistry, University of Tsukuba, for valuable advice and comments on the HPLC procedure.

\section{References}

1) Davis, E. F. 1928. The toxic principle of Juglans nigra as identified with synthetic juglone and its toxic effects on tomato and alfalfa plants. Amer. J. Bot. 15, 620 .

2 ) Goto, N. 1982. The relationship between characteristics of seed coat and dark-germination by gibberellin. Arabid. Inf. Serv. 19, 29-34.

3 ) Goto, N. 1985. A mucilage polysaccharide secreted from testa of Arabidopsis thaliana. Arabid. Inf. Serv. 22, 143-145.

4 ) Goto, N., S. Sando, Y. Sato and K. Hasegawa 1995. Effects of lepidimoide on growth and development of Arabidopsis thaliana. Weed Res., Japan 40 (2), 87-94.
5 ) Hasegawa, K., M. Amano, M. Urashima, H-H. Li and J. Mizutani 1992. Allelopathy of germinated cress seeds and tomato seedlings. Weed Res., Japan 37 (1), 68-71, (in Japanese)

6) Hasegawa, K., M. Amano and J. Mizutani 1992. Allelochemicals and antimicrobial substances produced from cress seedlings. Weed Res., Japan 37 (1), 71-73, (in Japanese)

7 ) Hasegawa, K., J. Mizutani, S. Kosemura and S. Yamamura 1992. Isolation and identification of lepidimoide, a new allelopathic substance from mucilage of germinated cress seeds. Plant Physiol. 100, 1059-1061.

$8)$ Hasegawa, K., M. Amano, C. Asakawa, H. Kakuta and J. Mizutami 1993. Elongation promoting activity of Amaranthus hypocotyls in mucilage of germinated seeds. Weed Res., Japan 38 (2), 109-111. (in Japanese)

9 ) Kato, Y., N. Ohnishi, S. Takahashi, Z-Y. Wang and T. Nozawa 1996. Screening of plant growth regulators acting on Arebidopsis thaliana. Biosci. Biotech. Biochem. 60 (1), 34-38.

10) Kobayashi, A., S. Morimoto, Y. Shibata, K. Yamashita and M. Numata 1980. C10polyacetylenes as allelopathic substances in dominants in early stages of secondary succession. J. Chem. Ecol. 6, 119-131.

11) Koornneef, M. 1981. The complex syndrome of ttg mutants. Arbid. Inf. Serv. 18. 45-51.

12) Kosemura, S., S. Yamamura, H. Kakuta, J. Mizutami and K. Hasegawa 1993. Synthesis and absolute configuration of lepidimoide, a high potent allelopathic substance from mucilage of germinated cress seeds. Tetrahedron Letteres $\mathbf{3 4}$ (16), 2653-2656.

13) Miyamoto, K., J. Ueda, K. Yamada, S. Kosemura, S. Yamamura and K. Hasegawa 1997. Inhibitory effect of lepidimoide on senescence in Avena leaf segments. J. Plant Physiol. 150, 133-136.

14) Miyamoto, K., J. Ueda, K. Yamada, S. Kosemura, S. Yamamura and K. Hasegawa 1997. Inhibition of abscission of bean petiole explants by lepidimoide. J. Plant Growth Regul. 16. 7-9.

15) Yamada K., T. Anai and K. Hasegawa 1995. Lepidimoide, an allelopathic substance in the exudates from germinating seeds. Phytochemistry 39 (5), 1031-1032.

16) Yamada K., T. Anai, S. Kosemura, S. Yamamura 
and K. Hasegawa 1996. Structure-activity relationship of lepidimoide and its analogues. Phytochemistry 41 (3). 671-673.

17) Yokotani-Tomita, K., N. Goto, S. Kosemura, S.
Yamamura and K. Hasegawa 1998. Growth promoting allelopathic substance exuded from germinating Arabidopsis thaliana seeds. Phytochemistry 47 (1), 1-2.
シロイヌナズナの成長中の植物組織に含まれる レピジモイド様物質及びその生理活性について

鍋谷 浩*・後藤伸治*・横谷一富田香織** 長谷川宏司 ${ }^{* *} \cdot$ 広瀬克利 $* * *$

\section{摘要}

レピジモイド（Fig. 1) は，はじめアレロパシー 物質としてクレス発芽種子から単離されたものであ る。しかし, 成長中のシロイヌナズナ(Arabidopsis thaliana)のロゼット葉, 茎十花序, および根の組織 にもレピジモイド様物質が含まれていることが, ケ イトウ（Celosia cristata）の幼植物を用いた生物試

\section{*宮城教育大学教育学部}

** 筑波大学応用生物化学系

****神戸天然物化学(侏)
験（Fig. 2）および HPLC における合成レピジモイ ドとのピークの一致 (Fig. 6) により確かめられた。 HPLC において合成レピジモイドと一致する分画は, ケイトウの胚軸伸長を促進し, 根の伸長を抑制した (Fig. 5)。また, これらの組織に含まれるレピジモ イド様物質 (限外ろ過による分子量 3000 以下の分画) は合成レピジモイドと同様の生理活性を示した。す なわち, シロイヌナズナ芽生えにおける胚軸と子葉 柄の伸長, および子葉の拡大成長を促進し, 根の伸 長を抑制した（Fig. 3, Fig. 4)。

これらの結果から, レピジモイド様物質はシロイ ヌナズナの成長中の組織で内生の成長調節物質とし て働いている可能性が示唆された。

キーワード：シロイヌナズナ, レピジモイド, 植物 成長調節物質, 成長促進, 成長抑制 